\title{
Reminiscence on the Impact of HIV on Infants and Children
}

\author{
James M Oleske* \\ Department of Pediatrics, Rutgers-New Jersey Medical School, USA
}

Submission: September 24, 2019; Published: October 01, 2019

*Corresponding author: James M Oleske, François-Xavier Bagnoud Distinguished Professor of Pediatrics, Department of Pediatrics, Rutgers-New Jersey Medical School, Newark, New Jersey, USA

\section{Opinion}

When I first graduated from Medical School in 1971, I believed medicine was at its heights with diagnosis and treatment guided by diagnostic procedures and well-developed therapeutic approaches that could cure most known diseases. How naive I was! As a new pediatrician, with an interest in infectious diseases and immunology, I first began to see patients in Newark, NJ after finishing my training in 1976. What I never expected and was unprepared for, as a young physician, was that there would be a new, never before seen disease, in the community I served! After first reporting the initial cases of this new disease in infants and children,similar to what was beingdescribed in IV drugusersand gay men with what was called "GRID-Gay Related Immunodeficiency Disease", I described "Acquired Immunodeficiency syndrome" transmitted from mothers to children published in the Journal of Allergy and Clinical Immunology in January of 1983. The increasing number of these patients I was seeing, led to the fortunate circumstance that a very generous and compassionate French Countess became aware of this crisis and awarded me the François-Xavier Bagnoud Chair of Pediatric Allergy, Immunology \& Infectious Diseases in 1991 to support this work. This award was in honor of her son François-Xavier Bagnoud, who died serving as a medical evacuation helicopter pilot during the Marathon des Sables race across the Saharan desert. Since then, there has been an evolution in my clinical and research activities from initially understanding clinical and laboratory correlates of allergy, immunodeficiency and infectious diseases to an appreciation of the impact of these illnesses and their progression to chronic illnesses on children and families. Particularly, HIV/AIDS in children has served as a paradigm for this evolution and has led to my expanding interest into the impact of disease on quality of life, including the need for palliative care, pain management and endof-life care. This also included the management of many neonates who were being born to mothers infected with HIV and who were unfortunately transmitting this new disease (HIV/AIDS) to their newly born infants either through in-utero transmission, during the birthing process or breast feeding. This somewhat paralleled our previous understanding of sexually transmitted diseases (syphilis, gonorrhea, chlamydia, etc.) that were passed through the placenta or during birth process from maternal secretions to the fetus directly. Perinatal HIV infection is no longer a major problem in the developed world were access to prenatal care is more uniformly available as screening for HIV has become universally implemented and treatment with Anti-Retroviral Therapies to prevent maternal to fetus transmission. Nevertheless, even in the US, there are pockets of poverty where underserved women who do not have access to appropriate prenatal care, accounting for the still few cases we see in the US.

As an outgrowth of these experiences in care for infants and children suffering from life-limiting and life-threatening conditions, my career has included the development of the non-profit foundation, Circle of Life Children's Center (COLCC), dedicated to providing Pediatric palliative and end-of-life care to infants and children with life-limiting, life-threatening conditions in New Jersey. The development of the COLCC was a direct outgrowth of my work and commitments as the FrançoisXavier Bagnoud Chair. It has been gratifying that over the last five years, our program has seen only two perinatally infected infants! In past years this number had been $\sim 20-30$ cases/yr. requiring lifelong treatment with multiple medications and before that I was attending multiple funerals per month from children dying of this disease. This achievement is directly related to the routine implementation of prophylaxis to prevent perinatal HIV infection in infected pregnant women and has become the standard of care across the world. In addition, currently HIV infected children living into adolescence can maintain good health and remain relatively symptom free, living a normal lifestyle through the successful development of life long antiretroviral therapy. Throughout my career, I have continued my public advocacy role for women, children and adolescents living with HIV infection and AIDS as well as children and adolescents with chronic life-threatening and limiting diseases that require palliative care, pain management and hospice/end-of-life care. 
The above admissions of a Newark, NJ Pediatrician from medical student to attending, can serve to continue the long tradition in medicine of our students learning, practicing and the teaching the next generation on the clinical imperatives of providing excellence and compassionate care for their patients while also providing advocacy and advancement in academic research. This is in addition to providing the education and experiential gains to the next generations of clinicians we train. This includes the role of the physician in continuing to be an educator/mentor for those students and young physicians in training. At the same time, as we mature and develop our skills, we must always continue to be vigilant for the next new or different threat occurring in our community that threatens its well being wither as a new infectious disease such as AIDS or a previously unrecognized autoimmune problem or the ever present and most times senseless trauma we inflict on each other with guns, tools and the environmental destruction we are currently experiencing.

This work is licensed under Creative Commons Attribution 4.0 Licens DOI: 10.19080/AJPN.2019.08.555787

\section{Your next submission with Juniper Publishers will reach you the below assets}

- Quality Editorial service

- Swift Peer Review

- Reprints availability

- E-prints Service

- Manuscript Podcast for convenient understanding

- Global attainment for your research

- Manuscript accessibility in different formats

( Pdf, E-pub, Full Text, Audio)

- Unceasing customer service

Track the below URL for one-step submission https://juniperpublishers.com/online-submission.php 